\title{
The role of the cytoskeleton in the polarized growth of the germ tube in Candida albicans
}

\author{
Tomohiro Akashi, Toshio Kanbe and Kenji Tanaka
}

Author for correspondence: Tomohiro Akashi.

Laboratory of Medical Mycology, Research Institute for Disease Mechanism and Control, Nagoya University School of Medicine, Showaku, Nagoya 466, Japan
Cells of the dimorphic yeast Candida albicans are easily induced to germinate in synchrony. Using germinating cells of strain FC18, we examined the effects of several drugs that are known to affect the cytoskeleton on growth and cytoskeletal organization. Cytochalasin A (CA), an inhibitor of actin function, inhibited the germination of the yeast cells and changed the cylindrical expansion of the apex of the germ tube to swelling growth. Effects of CA on the organization of actin were examined with rhodamine-phalloidin (Rh-Ph), which specifically stains F-actin. In CA-untreated cells, Rh-Ph staining resulted in condensed dot-like fluorescence at the growing tip, as well as filamentous fluorescence (actin cables) that ran from the apex to the basal region. In CA-treated cells, condensed dot-like fluorescence was still observed at the swelling tip, but actin cables had disappeared completely. This result indicates that CA does not affect the asymmetrical distribution of actin, and suggests that the actin cables are not required for maintenance of the polarized localization of actin. Benomyl, an anti-microtubule drug, inhibited the germination of yeast cells and the apical growth of germinated cells. Benomyl not only disrupted microtubules (MTs), but also affected the distribution of actin. In benomyl-treated cells, actin dots were randomly dispersed all over the cell. This result indicates that benomyl destroyed the mechanism that maintains the asymmetrical distribution of actin, and suggests that MTs are involved in such a mechanism. The polarized localization of organelles is one of the most important factors associated with dimorphism. Our data suggest that the cytoskeleton, composed of actin and MTs, is involved in the control of polarity in the hyphal growth of C. albicans, and that actin and MTs are interrelated in the establishment of polarity.

Keywords: Candida albicans, germ tube, actin, microtubules, cell polarity

\section{INTRODUCTION}

Candida albicans, a dimorphic yeast, grows by budding or as filamentous hyphae, depending on external conditions. This organism is a major opportunistic pathogen and infects tissues in its hyphal form. Many reports suggest a close relationship between the dimorphic transition and infection (see review by Odds, 1988). Analysis of the basic mechanism of the transition should be useful, not only in elucidating the mechanism of morphogenesis, but also in analysing the relationship between the dimorphic transition and infection.

Abbreviations: $C A(B, D, E)$, cytochalasin $A(B, D, E) ; C I P C$, isopropyl $N$ (3-chlorophenyl)carbamate; DAPI, 4',6'-diamidino-2-phenylindole; $M T$, microtubule; Rh-Ph, rhodamine-phalloidin.
Most types of growth and morphogenesis in the fungal kingdom are based on apical (tip) growth (Heath, 1990). Since the dimorphic transition can be regarded as a process whereby the type of growth is modified, it seems very likely that the transition involves the control of apical growth. The involvement of the cytoskeleton has been suggested in such control (Heath, 1990). The cytoskeleton is important for the localization and directed transport of cell constituents in many organisms. Since apical growth requires the asymmetrical arrangement of many constitutents of the cell, it can be assumed that the cytoskeleton is involved in the control of asymmetry in the apical growth of fungi and, consequently, that it affects growth and the dimorphic transition.

Among cytoskeletal components, actin is known to be the most important for apical growth in yeasts (Solomon, 
1991) and filamentous fungi (Heath, 1990). Fluorescence microscopy has revealed that F-actin accumulates at growing tips and in septating areas in both yeasts and filamentous fungi (Adams \& Pringle, 1984; Anderson \& Soll, 1986; Heath, 1990; Marks et al., 1986). In these areas, accumulation of many vesicles, which are presumed to be involved in the incorporation of new membrane and cellwall material, can be observed by electron microscopy (Akashi et al., 1993; Grove, 1978). The similarity in terms of distribution between actin and wall vesicles suggests that the accumulation of F-actin is probably involved in the localization of the vesicles. F-actin also forms a network of filaments in these organisms. Although the network of actin filaments is appropriately positioned to facilitate directed transport to the growing tip or the septum, its actual function is unclear (Drubin, 1990).

Another well-known cytoskeletal component is the microtubule (MT). In the yeast Saccharomyces cerevisiae, MTs are not essential for formation and growth of buds (Huffaker et al., 1988; Jacobs et al., 1988). In filamentous fungi, however, many researchers have pointed out the importance of MTs in apical growth (Caesar Ton That $e$ t al., 1988; Hoch \& Staples, 1985; Howard, 1981). This inconsistency may represent differences of growth habit. However, Herr \& Heath (1982) questioned the involvement of MTs in the hyphal growth of filamentous fungi, and the way in which MTs are involved in asymmetrical growth remains a subject of controversy.

Although there are many reports dealing with the dimorphic transition of $C$. albicans, the relationship between the cytoskeleton and the dimorphic transition in this organism is poorly understood. Structural aspects of actin and MTs in the yeast growth and in the hyphal growth of this organism have been addressed in detail by Anderson \& Soll (1986) and by Barton \& Gull (1988), respectively. Their studies revealed the divergent and dynamic behaviour of the cytoskeleton in the different growth forms. If we are to elucidate the role of the cytoskeleton in the dimorphic transition, further analyses are, however, necessary.

We examined the effects of several drugs that affect the functions of the cytoskeleton on hyphal growth, the yeastto-hypha transition and the cytoskeletal organization of C. albicans. Here we report that actin is involved in, but is not the sole factor required for, the control of apical growth in $C$. albicans, and that MTs are also involved in such control.

\section{METHODS}

Culture. Candida albicans strain FC18 (Magee et al., 1988) was used in this study. Cells were cultured in YPD medium $(1 \%$, $\mathrm{w} / \mathrm{v}$, yeast extract, $1 \%, \mathrm{w} / \mathrm{v}$, polypeptone, $2 \%, \mathrm{w} / \mathrm{v}$, glucose) overnight at $30^{\circ} \mathrm{C}$, transferted to YPD medium at $1 / 100$ dilution, and cultured for $4-5 \mathrm{~h}$ at $30^{\circ} \mathrm{C}$. The cells were harvested by centrifugation and suspended in distilled water (the $\mathrm{OD}_{660}$ of the suspension was $1-2$ after appropriate dilution). The suspension was incubated for $2-3 \mathrm{~h}$ or overnight at room temperature. Cells were then transferred to germination- induction medium [GI medium; YNB without amino acids and ammonium sulfate (Difco), $2 \%$ glucose, $0.2 \%$ bovine serum albumin, $20 \mathrm{mM}$ potassium phosphate buffer ( $\mathrm{pH} \mathrm{6.5)]} \mathrm{and}$ cultured for $15 \mathrm{~min}$ to $3 \mathrm{~h}$ at $37^{\circ} \mathrm{C}$. The cell density during the induction was adjusted to an $\mathrm{OD}_{660}$ of $0 \cdot 2-0 \cdot 3$.

Treatment with drugs. Cytochalasin A (CA; Sigma) was used at concentrations of $0 \cdot 2,1,5,20$ and $50 \mu \mathrm{M}$. Cytochalasins B, D and $\mathrm{E}(\mathrm{CB}, \mathrm{CD}$ and $\mathrm{CE}$, respectively; Sigma) were used at $50 \mu \mathrm{M}$. Benomyl, a kind gift from Dr Kamada, Department of Biology, Okayama University, Japan, was used at 1, 10, 50 and $100 \mu \mathrm{M}$. Isopropyl $N$-(3-chlorophenyl)carbamate (CIPC; Wako Pure Chemicals) was used at 0.5 and $1 \mathrm{mM}$. Drugs were added to the medium, at the given final concentrations, at the beginning of culture or after 45 min of culture in GI medium. In the experiment designed to examine the effects of treatment with $\mathrm{CA}$ and benomyl together, one drug was added to cells that had been cultured in GI medium for $45 \mathrm{~min}$ and the other was added to the culture $15 \mathrm{~min}$ later. In a parallel experiment, the order of administration of drugs was reversed.

Fluorescence microscopy. Cells were fixed in $3 \%(\mathrm{w} / \mathrm{v})$ formaldehyde in $50 \mathrm{mM}$ potassium phosphate buffer $(\mathrm{pH} 6.5$; PK buffer) for $2 \mathrm{~h}$ at room temperature. Microtubules were visualized by indirect-immunofluorescence staining by the method of Adams \& Pringle (1984). Fixed specimens were treated with Zymolyase $100 \mathrm{~T}\left(10 \mu \mathrm{g} \mathrm{ml}^{-1}\right.$; Seikagaku) at $30^{\circ} \mathrm{C}$ for $15 \mathrm{~min}$ and extracted with PK buffer that contained $0.1 \%$ Triton X-100. Then the specimens were incubated with rat monoclonal antibody against yeast- $\alpha$-tubulin (Serotec) which had been diluted $1: 100$ in PBS $(8 \mathrm{mM}$ phosphate buffer containing $137 \mathrm{mM} \mathrm{NaCl}$ and $2.7 \mathrm{mM} \mathrm{KCl}$ ), at $30^{\circ} \mathrm{C}$ for $2 \mathrm{~h}$ or at $4{ }^{\circ} \mathrm{C}$ overnight. The cells were stained with fluoresceinisothiocyanate-labelled goat antibodies against rat $\mathrm{IgG}$ (Organon Teknika) which had been diluted $1: 20$ in PBS, at $30^{\circ} \mathrm{C}$ for $1 \mathrm{~h}$. For staining of F-actin, fixed specimens were treated with PK buffer containing $0.1 \%$ Triton $\mathrm{X}-100$ and they were then stained with rhodamine-phalloidin ( $\mathrm{Rh}-\mathrm{Ph}$; Molecular Probes) which had been diluted $1: 20$ in PBS, at $30^{\circ} \mathrm{C}$ for $1 \mathrm{~h}$ or at $4{ }^{\circ} \mathrm{C}$ overnight. Nuclei were stained with $4^{\prime}, 6^{\prime}$-diamidino-2phenylindole $\left(1 \mu \mathrm{g} \mathrm{ml}^{-1}\right.$; DAPI) in PBS. Stained samples were examined with an epifluorescence microscope (BH-2-RFL; Olympus).

For counting of cells with concentrated actin fluorescence, cells with actin cables or cells with a single nucleus, at least 200 cells were examined in each sample. The figures show results typical of at least three experiments.

\section{RESULTS}

\section{Morphological changes and organization of the cytoskeleton in CA-treated cells}

C. albicans was induced to germinate efficiently and synchronously under our experimental conditions. When C. albicans FC18 cells, starved in distilled water, were transferred to GI medium, the cells began to germinate after $30 \mathrm{~min}$, and in more than $90 \%$ of the cells, cylindrical growth of the germ tube was observed after $50 \mathrm{~min}$. In preliminary experiments, we examined the effect of several cytochalasins on germination. The germination of FC18 cells was completely inhibited by CA at a concentration of $5 \mu \mathrm{M}$ or higher. Inhibition of germination was also observed with $\mathrm{CE}$ at $50 \mu \mathrm{M}$, but not with $\mathrm{CB}$ or $\mathrm{CD}$ at this concentration. We used CA for further experiments. 

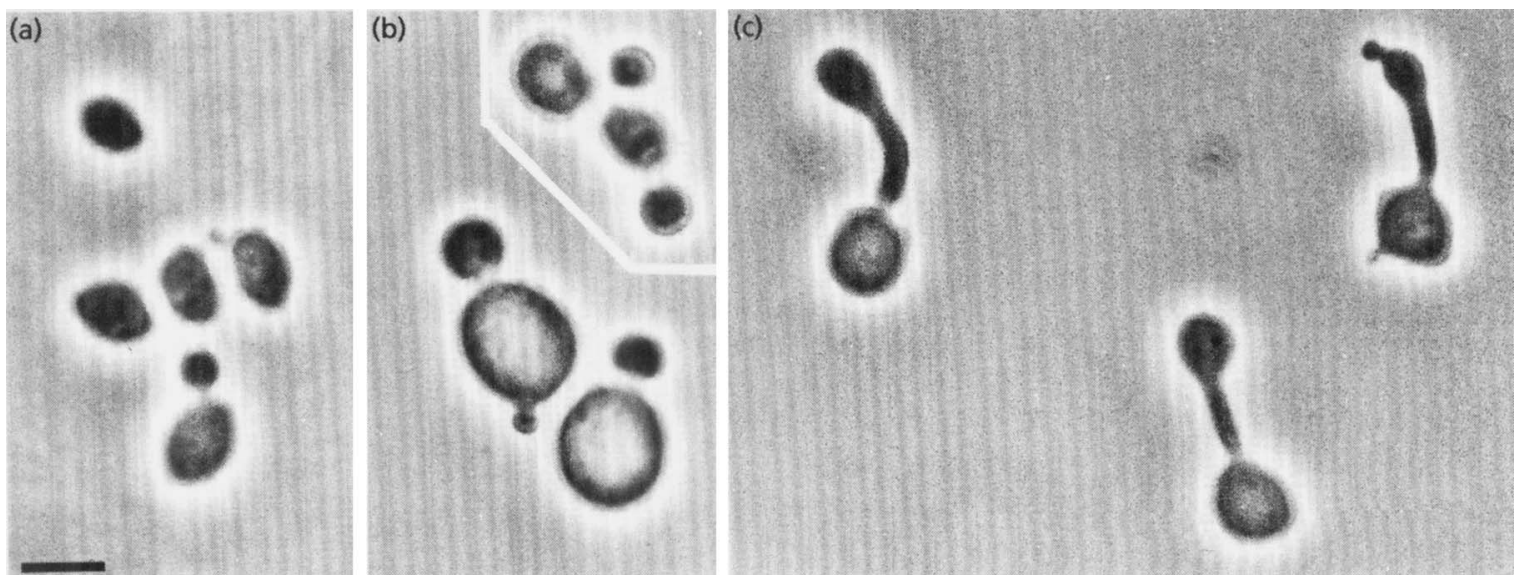

Fig. 1. Phase-contrast micrographs of cells treated with $5 \mu \mathrm{M} \mathrm{CA}$. (a) Cells cultured in Gl medium containing $5 \mu \mathrm{M}$ CA for $1 \mathrm{~h}$. (b) Cells cultured in GI medium with $5 \mu \mathrm{M}$ CA for $3 \mathrm{~h}$. The inset shows the cells before induction of germination. (c) Cells cultured in Gl medium for the first $45 \mathrm{~min}$ in the absence of CA and for the next $1 \mathrm{~h}$ in the presence of $5 \mu \mathrm{M} C A$ Bar, $5 \mu \mathrm{m}$.
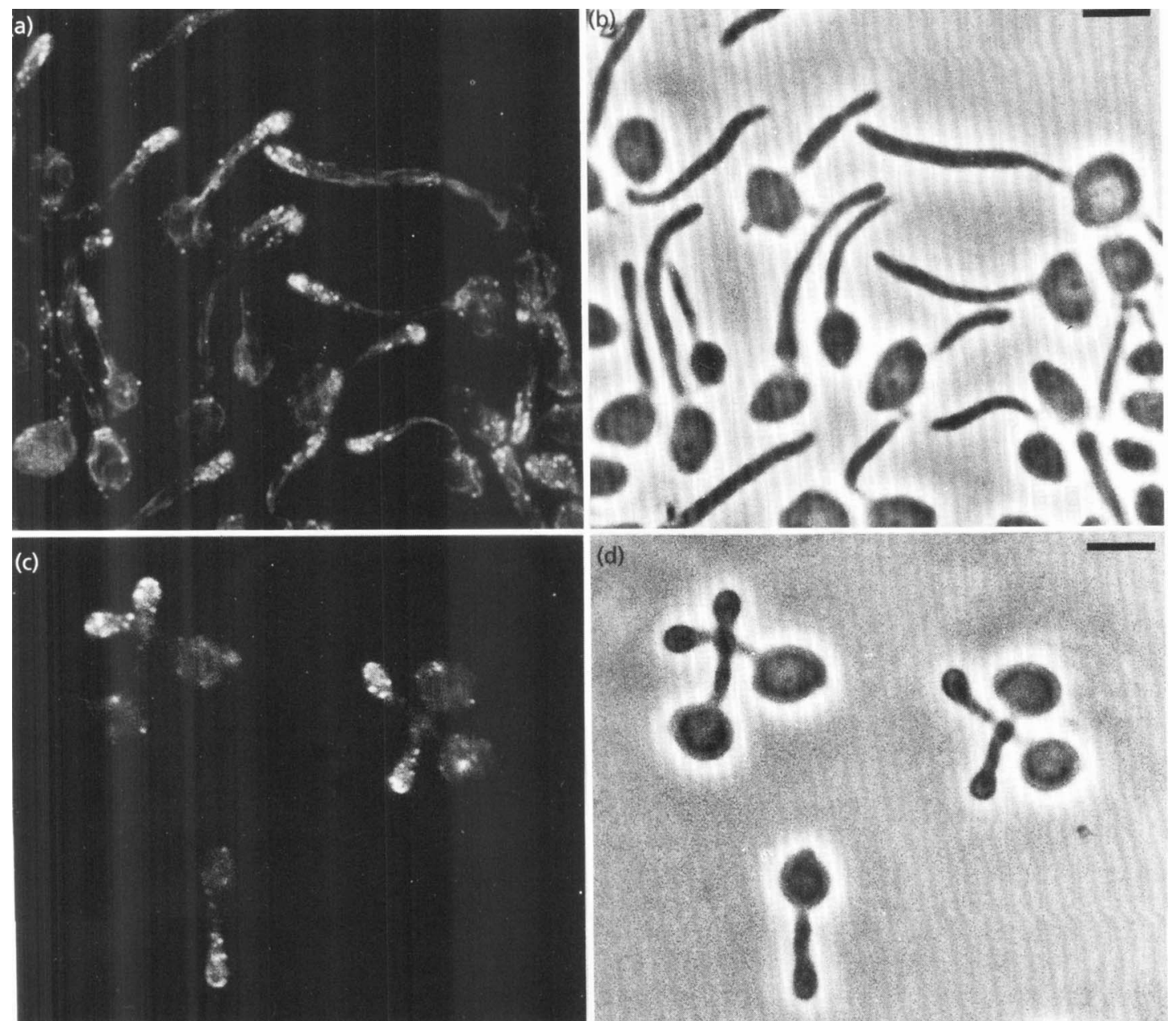

Fig. 2. Effects of $5 \mu \mathrm{MCA}$ on the organization of actin in germinated cells. $(a, b)$ Cells cultured in $\mathrm{Gl}$ medium in the absence of CA for $75 \mathrm{~min}$. (c, d) Cells cultured in Gl medium in the abserice of CA for the first 45 min and in the presence of $5 \mu \mathrm{M}$ CA for the next $30 \mathrm{~min}$. (a, c) Actin was stained with Rh-Ph. (b, d) Phase-contrast. Bars, $5 \mu \mathrm{m}$. 

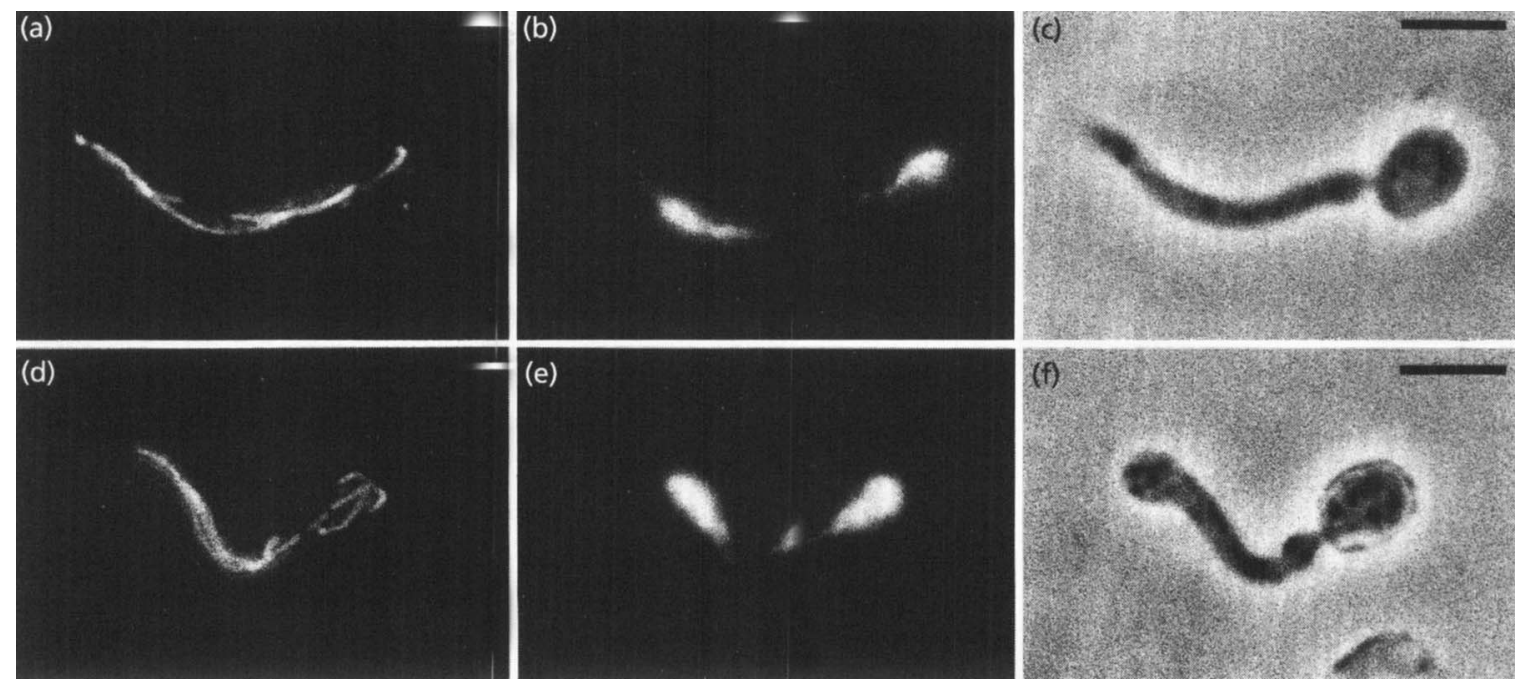

Fig. 3. Cells cultured in GI medium in the absence of CA for $75 \mathrm{~min}(a, b, c)$, and cells cultured in Gl medium in the absence of CA for the first $45 \mathrm{~min}$ and in the presence of $5 \mu \mathrm{M}$ CA for the next $30 \mathrm{~min}(\mathrm{~d}, \mathrm{e}, \mathrm{f}) .(\mathrm{a}, \mathrm{d}) \mathrm{MTs}$ immunostained with tubulin-specific antibody. (b, e) DAPI-stained nuclei. (c, f) Phase-contrast. Bars, $5 \mu \mathrm{m}$.

When $C$. albicans yeast cells were cultured in GI medium in the presence of $5 \mu \mathrm{M}$ CA, they did not germinate (Fig. 1a), but expanded isodiametrically, such that the cells became large spheres (Fig. 1b). At a concentration of $20 \mu \mathrm{M}$ or higher, cells neither germinated nor swelled (data not shown). Inhibition of germination by CA was reversed when the cells were washed free of CA. In an experiment where yeast cells that had been incubated in GI medium with $5 \mu \mathrm{M}$ CA for 30 min were transferred to CA-free GI medium, $96 \%$ of the cells germinated after $1 \mathrm{~h}$. After longer treatment with CA or treatment with higher concentrations, the recovery from the treatments was lower.

When CA was added at a final concentration of $5 \mu \mathrm{M}$ to germinated cells that had been incubated in GI medium for $45 \mathrm{~min}$, the cylindrical growth of germ tubes was inhibited and the tips of germ tubes began to swell (Fig. 1c). The spherical tips of CA-treated cells continued to expand for a few hours. At a concentration of $20 \mu \mathrm{M}$ or higher, even the swelling growth of the hyphal tip was inhibited (data not shown).

When germinated cells were stained with $\mathrm{Rh}-\mathrm{Ph}$, dense fluorescence, mainly composed of numerous dots (actin dots), was concentrated in the apical regions, and fluorescent filaments (actin cables) ran parallel to the hyphal axis in the germ tubes and in a meshwork in the mother cells (Fig. 2a, b). Cells cultured in GI medium for $75 \mathrm{~min}$ generally showed $88-95 \%$ of cells with concentrated fluorescence in the apex of the germ tube, and more than $99 \%$ of cells with actin cables. Some actin cables in germ tubes were thick, showing intense fluorescence. In germinated cells that had been treated with $5 \mu \mathrm{M} \mathrm{CA}$, many dots were concentrated in the swelling region of the germ tube, but no cables were observed (Fig. 2c, d). Cells cultured in CA-free medium for $45 \mathrm{~min}$ and in the medium containing $5 \mu \mathrm{M} \mathrm{CA}$ for a further $30 \mathrm{~min}$ had $90-95 \%$ of cells with concentrated fluorescence in the apex of the cells, and less than $1 \%$ of cells with actin cables. In germinated cells that had been treated with CA at $20 \mu \mathrm{M}$ or higher concentrations, concentrated fluorescence in apical regions was still observed (data not shown).

CA did not seem to affect MT organization and nuclear migration of germinated FC18 cells. When CA-untreated cells were observed by indirect-immunofluorescence staining with a tubulin-specific antibody, a few long MTs were observed (Fig. 3a, c). MT's in the germ tube were arranged parallel to the direction of growth. In most of the cells with two nuclei, one nucleus was seen near the apex, while the other was in the mother cell (Fig. 3b, c). In cells that had been treated with $5 \mu \mathrm{M} \mathrm{CA}$, MTs extended in the germ tube from the apex to the mother cell (Fig. $3 \mathrm{~d}, \mathrm{f})$. In the cells with two nuclei, one of the nuclei was usually located near or at the apex of the germ tube, while the other was in the mother cell (Fig. $3 e, f$ ).

To examine changes in the organization of actin and the effects of $\mathrm{CA}$ on the changes during the transition from yeast cells to hyphae, we examined the distribution of actin during the transition in the absence and presence of CA. Before transfer to GI medium, the starved cells had a few large actin dots (Fig. 4a, b). In cells 15 min after induction of germination, many small, uniformly distributed dots were seen in place of the large ones (Fig. 4c). At the time when cells began to germinate, bright fluorescence was observed, concentrated in a localized area in most cells after $\mathrm{Rh}-\mathrm{Ph}$ staining (Fig. $4 \mathrm{~d}$ ). When starved cells were transferred to GI medium that contained $5 \mu \mathrm{M}$ CA, many small dots were dispersed within the cells after 15 min (Fig. 4e), but they did not gather 

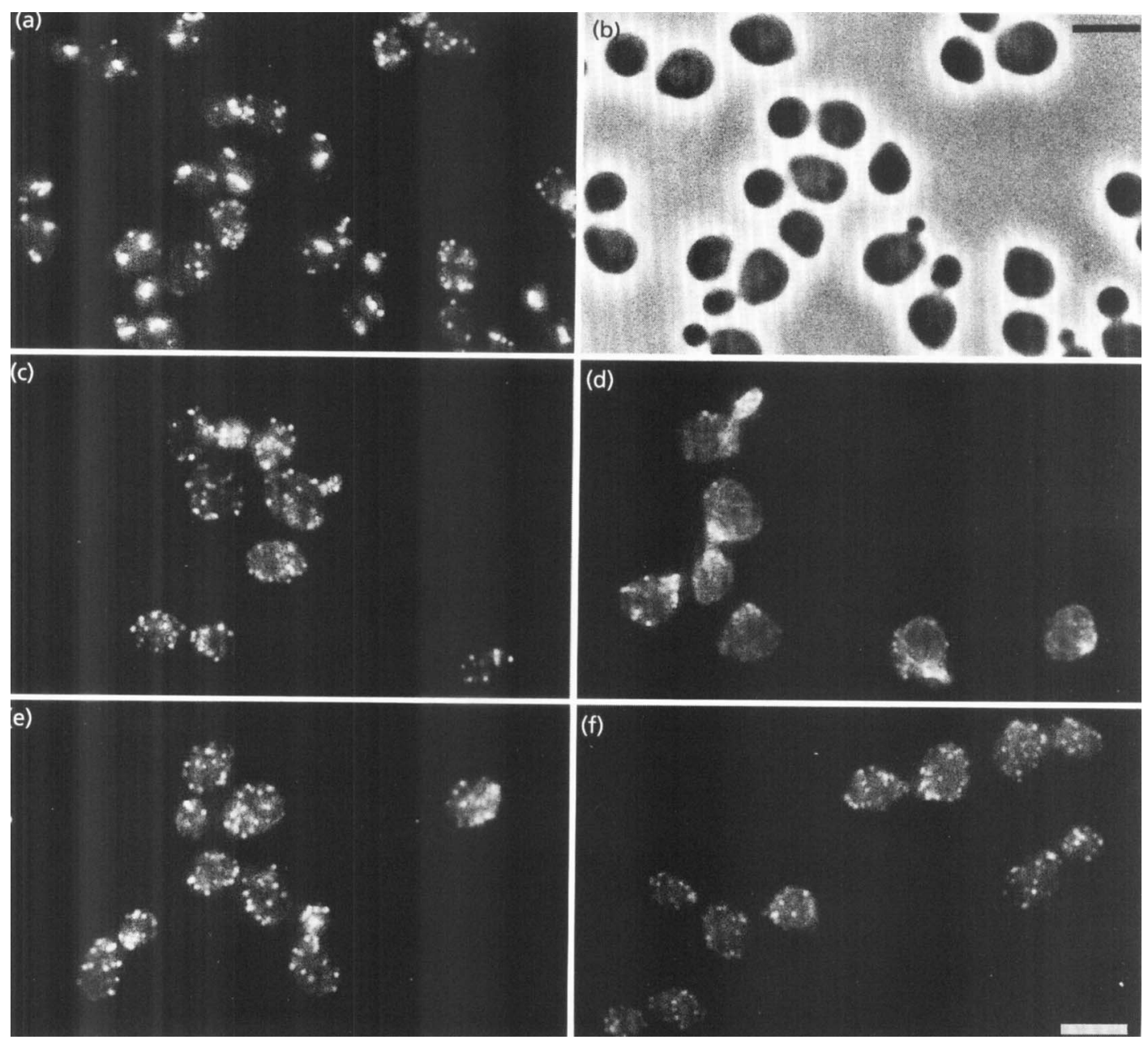

Fig. 4. Fluorescence and phase-contrast micrographs of cells stained with Rh-Ph showing the distribution of actin after induction of germination in the absence of $C A(a, b, c, d)$ and in the presence of $5 \mu M C A(e, f) .(a, b)$ At zero time. (c,e) $15 \min$. (d, f) $25 \mathrm{~min}$. Bar, $5 \mu \mathrm{m}$.

together after further incubation in the germination medium (Fig. 4f).

\section{Organization of actin in cells treated with anti-MT drugs}

Among various anti-MT drugs tested, benomyl was found to inhibit germination of FC18 yeast cells effectively. Benomyl at a concentration of $50 \mu \mathrm{M}$ or higher inhibited both the germination of yeast cells and the hyphal growth of germinated cells. The inhibition of germination was reversed when the cells were washed free of benomyl. When yeast cells that had been incubated in GI medium with $1(10 \mu \mathrm{M}$ ben benomyl-free GI medium, $97 \%$ of the cells germinated after $1 \mathrm{~h}$.

The asymmetrical distribution of actin was found to be disturbed by benomyl. When germinated cells that had been treated with $100 \mu \mathrm{M}$ benomyl for $30 \mathrm{~min}$ were stained with $\mathrm{Rh}-\mathrm{Ph}$, actin dots were distributed all over the cells without particular localization (Fig. 5a, b). When yeast cells that had been germinated for $45 \mathrm{~min}$ were treated with $50 \mu \mathrm{M}$ benomyl for $30 \mathrm{~min}, 3 \%$ of cells showed dense fluorescence in the apex of germ tubes, $19 \%$ of cells showed no such localized dense fluorescence but still had more fluorescence in germ tubes than in mother cells, and $78 \%$ of cells showed equal distribution of fluorescence. Although thick actin cables were not observed in benomyl-treated cells, minute filamentous fluorescence due to actin was still observed in $75-85 \%$ of the cells (Fig. 5a).

Treatment with benomyl caused an extreme decrease in numbers of MTs. After a 30 min treatment with $100 \mu \mathrm{M}$ benomyl, the cells had no MTs or only short ones (Fig. $7 \mathrm{a}, \mathrm{b}, \mathrm{c})$. Since the remaining MTs were almost all associated with their dividing nucleus (see the left cell of Fig. 7), the MTs were assumed to be spindle MTs, and therefore almost all cytoplasmic M'Ts were assumed to 

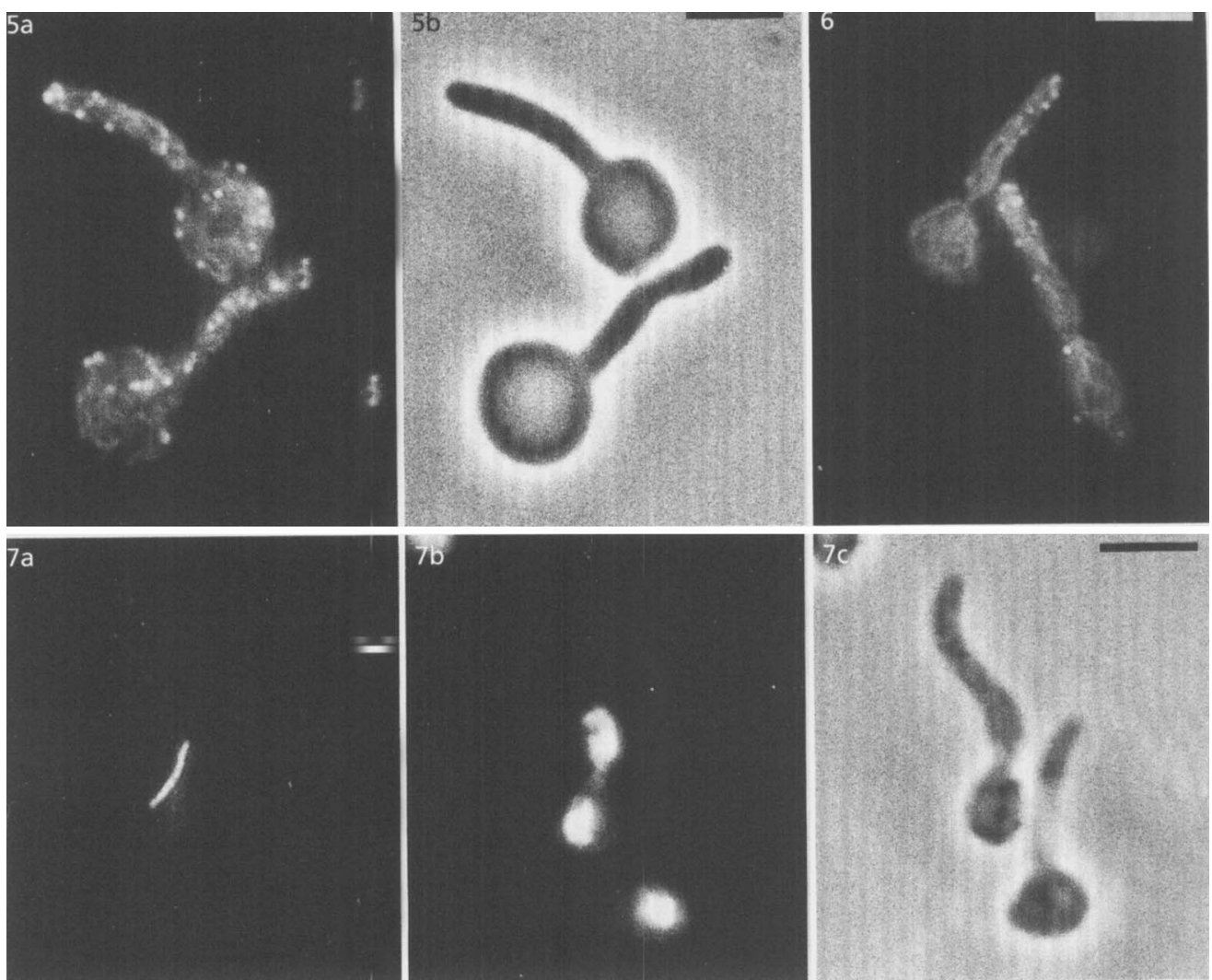

Fig. 5. Cells treated with $100 \mu \mathrm{M}$ benomyl. Cells that had germinated for $\mathbf{4 5}$ min were cultured for the next 30 min in the presence of $100 \mu \mathrm{M}$ benomyl. (a) Actin is shown by Rh-Ph staining. Actin dots are dispersed over the entire cell. (b) Phase-contrast. Bar, $5 \mu \mathrm{m}$.

Fig. 6. Cells treated with $0.5 \mathrm{mM} \mathrm{CIPC}$. Cells that had germinated for $45 \mathrm{~min}$ were cultured for the next $30 \mathrm{~min}$ in the presence of $0.5 \mathrm{mM}$ CIPC. Actin is shown by Rh-Ph staining. Bar, $5 \mu \mathrm{m}$.

Fig. 7. Cells that had germinated for $45 \mathrm{~min}$ were cultured for the next $30 \mathrm{~min}$ in the presence of $100 \mu \mathrm{M}$ benomyl. (a) MTs immunostained with tubulin-specific antibody. Cytoplasmic MTs were not detected. (b) DAPI. (c) Phase-contrast. Bar, $5 \mu \mathrm{m}$.

disappear as a result of benomyl treatment. Benomyl seemed to affect nuclear division and/or nuclear migration. Cells incubated in GI medium for $45 \mathrm{~min}$ showed $80-85 \%$ of cells with a single nucleus and $10-15 \%$ of cells with a dividing nucleus, located near the neck of the germ tube. Cells incubated for a further $30 \mathrm{~min}$ in benomyl-free GI medium showed 15-20\% of cells with two nuclei away from each other (See Fig. 3). Cells incubated in GI medium containing $50 \mu \mathrm{M}$ benomyl for a further $30 \mathrm{~min}$, however, showed few cells with two separate nuclei and $10-15 \%$ of cells with a dividing nucleus, as shown by cells before benomyl treatment.

CIPC, known to have anti-MT effects, inhibited germination and growth of the germ tube at a concentration of $0.5 \mathrm{mM}$ or higher (data not shown). CIPC caused disorganization of actin dots and disappearance of thick actin cables, although minute filamentous fluorescence due to actin was observed in these cells (Fig. 6). CIPC also caused an extreme decrease in the numbers of MTs (data not shown).

\section{Effects of treatment with benomyl and CA together on the organization of actin}

Benomyl caused disorganization of actin, but CA did not. To examine whether benomyl could disorganize the polarized distribution of actin in CA-treated cells, we added benomyl to germinated cells that had been pretreated with CA. After cells had been induced to germinate in GI medium for $45 \mathrm{~min}$, they were treated with $5 \mu \mathrm{M}$ CA for $15 \mathrm{~min}$ and then with $100 \mu \mathrm{M}$ benomyl for $30 \mathrm{~min}$. $\mathrm{Rh}-\mathrm{Ph}$ staining of these cells revealed that their actin dots were still located in the apical region (Fig. 8a, b). The tips of the cells did not expand further after treatment with benomyl. To determine whether CA itself caused localization of actin dots, we added CA to germinated cells that had been pre-treated with benomyl. Cells that had been induced to germinate for $45 \mathrm{~min}$ were cultured in GI medium containing $100 \mu \mathrm{M}$ benomyl for $15 \mathrm{~min}$, and then $\mathrm{CA}$ at $5 \mu \mathrm{M}$ was added to the medium. In these cells, actin dots were distributed randomly, and no actin cables were observed (Fig. 8c, d). 

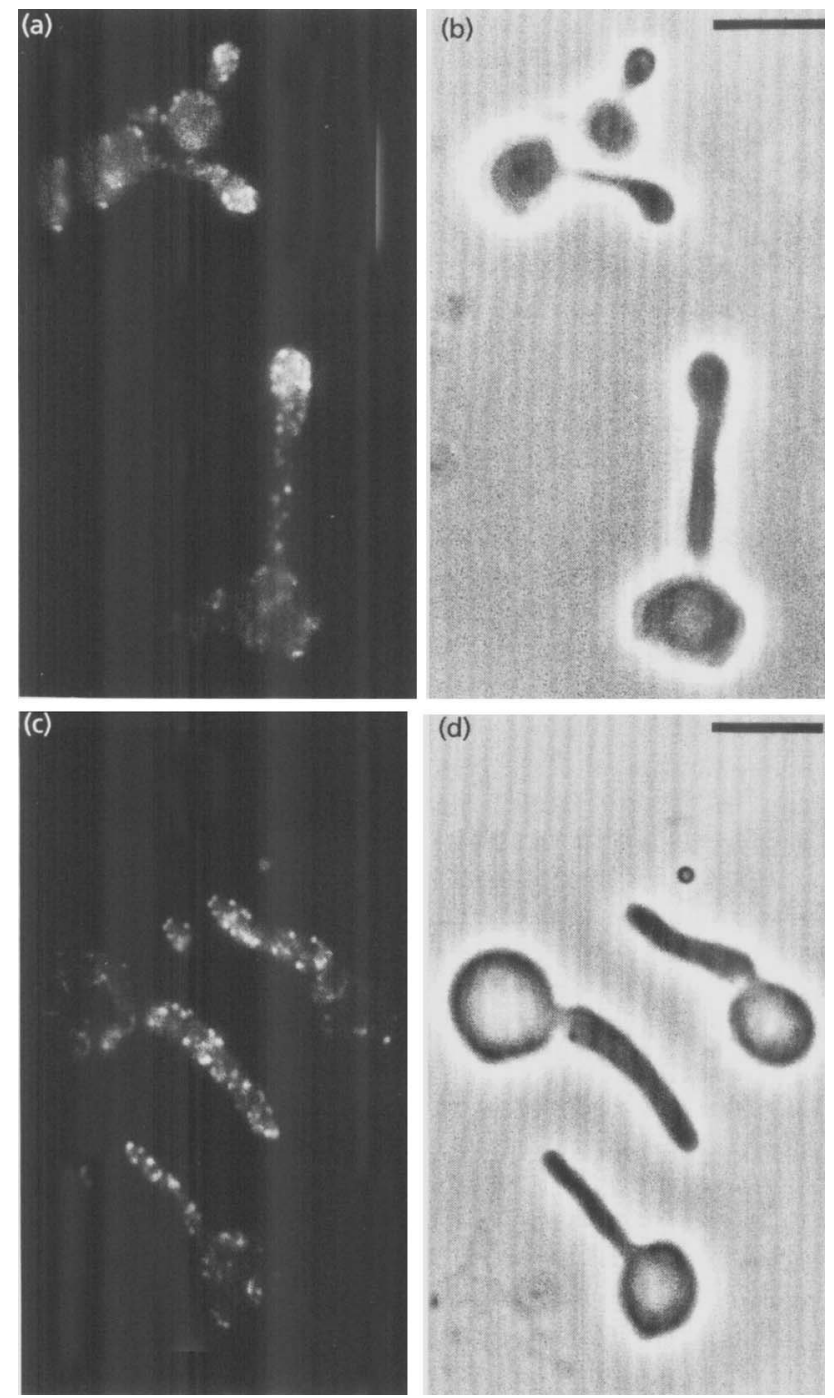

Fig. 8. Cells treated with both $5 \mu \mathrm{M} C A$ and $100 \mu \mathrm{M}$ benomyl. $(a, b)$ Cells that had germinated for 45 min were cultured in the presence of $5 \mu \mathrm{M} C A$ for the first $15 \mathrm{~min}$, and then in the presence of both $5 \mu \mathrm{MCA}$ and $100 \mu \mathrm{M}$ benomyl for the next $30 \mathrm{~min}$. (c, d) Cells that had germinated for $45 \mathrm{~min}$ were cultured in the presence of $100 \mu \mathrm{M}$ benomyl for the first $15 \mathrm{~min}$, and then in the presence of both $5 \mu \mathrm{M} \mathrm{CA}$ and $100 \mu \mathrm{M}$ benomyl for the next 30 min. (a, c) Stained with Rh-Ph. (b, d) Phase-contrast. Bar, $5 \mu \mathrm{m}$

\section{DISCUSSION}

Addition of CA changed the apical growth of C. albicans FC18 germinated cells from cylindrical to spherical (Fig. 9a). This change suggests that the growing tips lost their ability to control the direction of growth as a result of the treatment. Similar spherical growth upon treatment with cytochalasin was reported in the case of the hyphal growth of several fungi (Grove \& Sweigard, 1980; Jackson \& Heath, 1990; Staples \& Hoch, 1982; Tucker et al., 1986). These results indicate that the cytochalasins cause swelling during apical growth of fungi by a common mechanism. CA is a cytochalasin, a member of a family of (a)

(i)

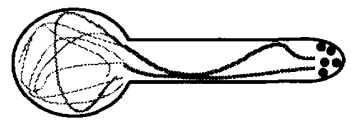

(ii)

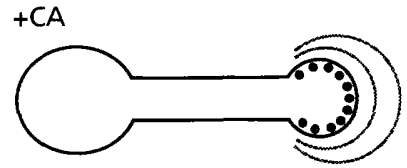

(iii)

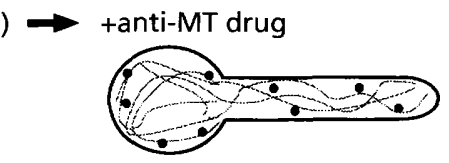

(b)

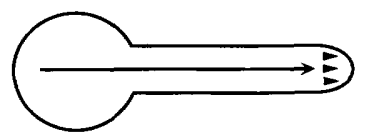

(i)

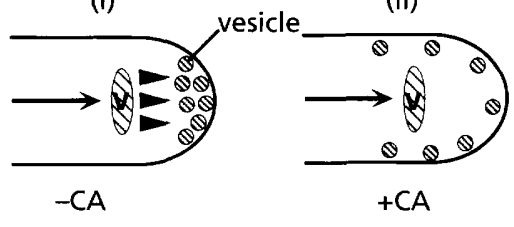

Fig. 9. Schematic representation of the effects of CA and antiMT drugs on the organization of actin in germinated cells of $C$. albicans. In a drug-untreated cell (i), actin dots accumulate in the apical region, and actin cables run all over the cell. Cables in the tube are thick. In a CA-treated cell (ii), the apex grows isodiametrically, and actin dots accumulate at the spherical apex. Cables disappear. In a cell treated with an anti-MT drug (iii), the growth stops. Actin dots are dispersed throughout the cell, and feeble actin cables are distributed in a meshwork. (b) A proposed mechanism for the effect of CA on hyphal growing cells. Arrows indicate CA-insensitive overall polarity, and arrowheads indicate CA-sensitive localized polarity. In a CAuntreated cell (i), the destination of vesicles, supplied from the vesicle-supply centre $(V)$, is restricted to a narrow region as a result of actin-based polarity. In a CA-treated cell (ii), actinbased polarity disappears, with resultant loss of polarized localization of vesicles.

drugs that inhibit polymerization of actin in vitro and affect cellular events in vivo that involve actin (Yahara et al., 1982). Since actin is believed to play an important role in apical growth in fungi (Heath, 1990), the morphological changes due to CA are likely to result from its actions on actin. In $S$. cerevisiae, spherical expansion without budding was reported in mutants with defects in actin (Novick \& Botstein, 1985) and actin-related proteins (Haarer et al., 1990; Johnston et al., 1991), suggesting a close relationship between defects in actin function and spherical expansion. This similarity also supports the hypothesis that the spherical expansion, caused by CA in germinated C. albicans cells, results from inhibition of actin function. Although CA caused spherical growth in the apical region of germinated cells, the growth of each entire cell was still restricted to the apical region after treatment with CA. From this result, it seems that the polarity of each cell remains, even after treatment with CA. This hypothesis is 
supported by the distribution of actin dots in CA-treated germinated cells; the dots were restricted at the apical region of CA-treated germinated cells (Fig. 9a), even in cells treated with $\mathrm{CA}$ at higher concentrations. These results suggest the existence of specific polarity that is involved in the asymmetry of growth and the distribution of actin as a whole in germinated cells. It was reported that localization of actin in the apical region was not disturbed by treatment of Uromyces phaseoli (Tucker et al., 1986) and Saprolegnia ferax (Jackson \& Heath, 1990) with $\mathrm{CE}$. These results suggest that polarity that is resistant to cytochalasins is common in hyphal growing cells.

In $C$. albicans yeast cells that had been cultured in GI medium for $25 \mathrm{~min}$, the polarized distribution of actin appeared synchronously in all cells. In the presence of CA, however, no polarized distribution of actin was apparent. The CA-treated yeast cells showed no polarized growth, and only swelling growth was observed. These results coincide with the notion that the polarized distribution of actin is deeply involved in polarized growth. Non-polar swelling growth caused by CA was also observed in the apical region of germinated cells. While it was unclear, because of the problem of resolution, whether the polarized distribution of actin was present in the small apical region, it is likely that loss of asymmetry of actin localization also occurred in the apical region of CAtreated germinated cells.

In germinated cells of $C$. albicans, CA seemed to destroy polarity only in the apical region, and not in the whole cell. This result suggests that actin is responsible for 'localized polarity', and that factors other than actin exist to maintain 'overall polarity' in germinated cells (Fig. 9b). The CA-treated yeast cells showed only CA-sensitive polarity. By contrast, the germinated cells showed CAresistant, overall polarity. Overall polarity may be established after germination.

Although CA did not affect the apparent distribution of actin dots in germinated cells, actin cables completely disappeared after treatment with CA. This result indicates that actin cables are not required for the maintenance of overall polarity, and is consistent with the result that the actin cables observed in benomyl-treated cells were insufficient to sustain the asymmetrical localization of the actin dots. In $S$. cerevisiae, the function of actin cables is controversial; some mutants without actin cables exhibited normal budding growth (Adams et al., 1989; Liu \& Bretscher, 1989).

In benomyl-treated germinated cells, actin dots were distributed randomly all over the cells (Fig. 9a). In CApretreated cells, by contrast, polarization of actin was not disrupted by benomyl. This apparent inconsistency may be explained by postulating that CA acts to prevent the redistribution of actin dots. In plant cells, a network of actin filaments is responsible for cytoplasmic streaming (Kamiya, 1981). CB is known to cause the cessation of cytoplasmic streaming (Ishigami \& Nagai, 1980). Benomyl could not disperse the actin dots in CApretreated cells perhaps because of damage to a circulating process as in the case of inhibition of cytoplasmic streaming by CA. In the cells treated only with benomyl, a network of actin cables was observed, but it was not seen in CA-pretreated cells. The network of actin cables may be involved in a process that resembles cytoplasmic streaming.

Our data suggested the existence of factor(s) other than actin that sustain the overall polarity of growth and the organization of actin in germinated $C$. albicans cells. We examined the effects of the anti-MT drugs benomyl and CIPC on the organization of actin, and we found that both drugs dispersed actin dots randomly in the same manner (Fig. 9a). The random distribution of actin dots caused by CIPC was also reported in other strains of $C$. albicans by Yokoyama et al. (1990). These results indicate that the drugs inactivated the mechanism required to sustain the asymmetrical distribution of actin dots. The disorganization of actin by benomyl and CIPC may be simply interpreted as a result of the cessation of growth due to the drug treatments. In cells treated with $20 \mu \mathrm{M}$ or higher concentrations of CA, however, growth stopped completely as in cells treated with benomyl or CIPC, but CA did not disperse actin dots. Once cells had been treated with CA, benomyl did not disrupt actin distribution. These examples indicate that cessation of growth alone cannot explain the disappearance of organization of actin. Considering that these drugs destroyed cytoplasmic MTs almost completely in germinated $C$. albicans cells and that these drugs are known to have anti-MT activities, it is plausible that the disorganization of actin dots by benomyl and CIPC resulted from the inhibition of MT function by the drugs. Although the effect of CIPC as an anti-MT drug is controversial (Oliver et al., 1978), benomyl has been shown to be highly specific to M'Ts in fungi (Davidse \& Flach, 1977; Huffaker et al., 1988; Orbach et al., 1986; Thomas et al., 1985). These results support the hypothesis that MTs are involved in the mechanism that sustains the asymmetrical distribution of actin dots.

In S. cerevisiae, MTs are known to be unrelated to polarized growth during budding (Huffaker et al., 1988; Jacobs et al., 1988). However in our study with C. albicans FC18 cells, MTs seemed necessary for maintenance of the overall polarity of hyphal growth. These contrasting results may reflect the difference between budding growth and hyphal growth.

With respect to the mechanisms that control apical growth in fungi, Bartnicki-Garcia et al. (1989) proposed that the vesicle-supply centre is a critical determinant of morphogenesis in fungi. The linear displacement of the centre generates cylindrical growth of hyphae, and a cell without such displacement grows as a sphere. Applying our results to this hypothesis (Fig. 9b), we find that, in CA-treated germinated cells, the centre seems to function but its displacement seems to be inhibited. If the effect of CA that we observed is due to the inhibition of actin function, it can be assumed that actin is related to the forward displacement of the centre (Fig. 9b).

Bartnicki-Garcia et al. (1989) also showed that the vesiclesupply centre coincided with the Spitzenkörper, a structure observed in the apex of growing hyphae. Howard \& 
Aist (1980) reported that the Spitzenkörper was disturbed by an anti-MT drug in Fusarium acuminatum, suggesting that MTs are involved in hyphal growth via their interaction with such a structure. Inhibition of hyphal growth of germinated $C$. albicans cells by anti-MT drugs may result from inhibition of the functions of such structures, although in yeasts, including $C$. albicans, no analogue of the Spitzenkörper has yet been found. MTs are related to the localization of organelles in most organisms, for example, to the positioning of Golgi bodies (Thyberg \& Moskalewski, 1985) and the transport of cell organelles (Vale, 1987) in mammalian cells. In fungi, relationships between the cytoskeleton and movement of organelles are not necessarily obvious. For a further understanding of the function of the cytoskeleton in dimorphism, we must study the relationships between the cytoskeleton and other molecules and cellular constituents, including organelles.

\section{ACKNOWLEDGEMENTS}

We are very grateful to Dr T. Kamada for the gift of benomyl. This work was supported in part by a Grant-in-Aid (no. 04740388) for Scientific Research from the Ministry of Education, Science and Culture of Japan.

\section{REFERENCES}

Adams, A. E. M. \& Pringle, J. R. (1984). Relationship of actin and tubulin distribution to bud growth in wild-type and morphogenetic-mutant Saccharomyces cerevisiae. J Cell Biol 98, 934-945.

Adams, A. E., Botstein, D. \& Drubin, D. G. (1989). A yeast actinbinding protein is encoded by SAC6, a gene found by suppression of an actin mutation. Ficience 243, 231-233.

Akashi, T., Homma, M., Kanbe, T. \& Tanaka, K. (1993). Ultrastructure of proteinase-secreting cells of Candida albicans studied by alkaline bismuth staining and immunocytochemistry. I Gen Microbiol 139, 2185-2195.

Anderson, J. M. \& Soll, D. R. (1986). Differences in actin localization during bud and hypha formation in the yeast Candida albicans. / Gen Microbiol 132, 2035-21647.

Bartnicki-Garcia, S., Hergert, F. \& Gierz, G. (1989). Computer simulation of fungal morphogenesis and the mathematical basis for hyphal (tip) growth. Protoplasma 153, 46-57.

Barton, R. \& Gull, K. (1988). Variation in cytoplasmic microtubule organization and spindle length between the two forms of the dimorphic fungus Candida albicans. J Cell Sci 91, 211-220.

Caesar Ton That, T. C., Rossier, C., Barja, F., Turian, G. \& Roos, U. P. (1988). Induction of multiple germ tubes in Neurospora crassa by antitubulin agents. Eur J Cell Biol 46, 68-79.

Davidse, L. C. \& Flach, W. (1977). The mechanism of tesistance to the antitubulin methyl benzimidazole-2-yl carbamate in the fungus Aspergillus nidulans. J Cell Biol 72, 174-193.

Drubin, D. G. (1990). Actin and actin-binding proteins in yeast. Cell Motil Cytoskeleton 15, - - 11.

Grove, S. N. (1978). The cytology of hyphal tip growth. In The Filamentous Fungi, pp. 28-50. Edited by J. E. Smith \& D. R. Berry. London: Edward Arnold.

Grove, S. N. \& Sweigard, J. A. (1980). Cytochalasin A inhibits spore germination and hyphal tip growth in Gibertella persicaria. Exp Mycol 4, 239-250.

Haarer, B. K., Lillie, S. H., Adams, A. E. M., Magdolen, V.,
Bandlow, W. \& Brown, S. S. (1990). Purification of profilin from Saccharomyces cerevisiae and analysis of profilin-deficient cells. J Cell Biol 110, 105-114.

Heath, I. B. (1990). The role of actin in tip growth of fungi. Int Rev Cytol 123, 95-127.

Herr, F. B. \& Heath, M. C. (1982). The effects of antimicrotubule agents on organelle positioning in the cowpea rust fungus, Uromyces phaseoli var. vignae. Exp Mycol 6, 15-24.

Hoch, H. C. \& Staples, R. C. (1985). The microtubule cytoskeleton in hyphae of Uromyces phaseoli germlings: its relationship to the region of nucleation and to the F-actin cytoskeleton. Protoplasma 124, 112-122.

Howard, R. J. (1981). Lltrastructural analysis of hyphal tip cell growth in fungi: spitzenkorper, cytoskeleton and endomembranes after freeze-substitution. J Cell Si 4 48, 89-103.

Howard, R. J. \& Aist, J. R. (1980). Cytoplasmic microtubules and fungal morphogenesis: ultrastructural effects of methyl benzimidazole-2-ylcarbamate determined by freeze-substitution of hyphal tip cells. J Cell Biol 87, 55-64.

Huffaker, T. C., Thomas, J. H. \& Botstein, D. (1988). Diverse effects of $\beta$-tubulin mutations on microtubule formation and function. J Cell Biol 106, 1997-2010.

Ishigami, M. \& Nagai, R. (1980). Motile apparatus in I' allisneria leaf cells. II. Effects of cytochalasin B and lead acetate on the rate and direction of streaming. Cell Struct Funct 5, 13-20.

Jackson, S. L. \& Heath, I. B. (1990). Evidence that actin reinforces the extensible hyphal apex of the oomycete Saprolegnia ferax. Protoplasma 157, 144-153

Jacobs, C. W., Adams, A. E. M., Szaniszlo, P. J. \& Pringle, J. R. (1988). Functions of microtubules in the Saccharomyces cerevisiae cell cycle. J Cell Biol 107, 1409-1426.

Johnston, G. C., Prendergast, J. A. \& Singer, R. A. (1991). The Saccharomyces cerevisiae MYO2 gene encodes an essential myosin for vectorial transport of vesicles. J Cell Biol 113, 539-551.

Kamiya, N. (1981). Physical and chemical basis of cytoplasmic streaming. Annu Rev Plant Physiol 32, 205-236.

Liu, H. \& Bretscher, A. (1989). Disruption of the single tropomyosin gene in yeast results in the disappearance of actin cables from the cytoskeleton. Cell 57, 233-242.

Magee, B. B., Koltin, Y., Gorman, J. A. \& Magee, P. T. (1988). Assignment of cloned genes to the seven electrophoretically separated Candida albicans chromosomes. Mol Cell Biol 8, 4721-4726. Marks, J., Hagan, I. M. \& Hyams, J. S. (1986). Growth polarity and cytokinesis in fission yeast: the role of the cytoskeleton. J Cell Sci Suppl 5, 229-241.

Novick, P. \& Botstein, D. (1985). Phenotypic analysis of temperature-sensitive yeast actin mutants. Cell 40, 405-416.

Odds, F. C. (1988). Candida and Candidosis. London: Bailliere Tindall.

Oliver, J. M., Krawiec, J. A. \& Berlin, R. D. (1978). A carbamate herbicide causes microtubule and microfilament disruption and nuclear fragmentation in fibroblasts. Exp Cell Res 116, 229-237.

Orbach, M. J., Porro, E. B. \& Yanofsky, C. (1986). Cloning and characterization of the gene for $\beta$-tubulin from a benomyl-resistant mutant of Neurospora crassa and its use as a dominant selectable marker. Mol Cell Biol 6, 2452-2461.

Solomon, F. (1991). Analyses of the cytoskeleton in Saccharomyces cerevisiae. Annu Rev Cell Biol 7, 633-662.

Staples, R. C. \& Hoch, H. C. (1982). A possible role for microtubules and microfilaments in the induction of nuclear division in bean rust uredospore germlings. Exp Mycol 6, 293-302. 
Thomas, J. H., Neff, N. F. \& Botstein, D. (1985). Isolation and characterization of mutations in the $\beta$-tubulin gene of Saccharomyces serevisiae. Genetics 112, 715-734.

Thyberg, J. \& Moskalewski, S. (1985). Microtubules and the organization of the Golgi complex. Exp Cell Res 159, 1-16.

Tucker, B. E., Hoch, H. C. \& Staples, R. C. (1986). The involvement of F-actin in Uromyces cell differentiation: the effects of cytochalasin E and phalloidin. Protoplasma 135, 88-101.

Vale, R. D. (1987). Intracellular transport using microtubule-based motors. Annu Rev Cell Biol 3, 347-378.
Yahara, I., Harada, F., Sekita, S., Yoshihira, K. \& Natori, S. (1982). Correlation between effects of 24 different cytochalasins on cellular structures and cellular events and those on actin in vitro. J Cell Biol 92, 69-78.

Yokoyama, K., Kaji, H., Nishimura, K. \& Miyaji, M. (1990). The role of microfilaments and microtubules in apical growth and dimorphism of Candida albicans. J Gen Microbiol 136, 1067-1075.

Received 17 May 1993; revised 9 August 1993; accepted 8 September 1993. 